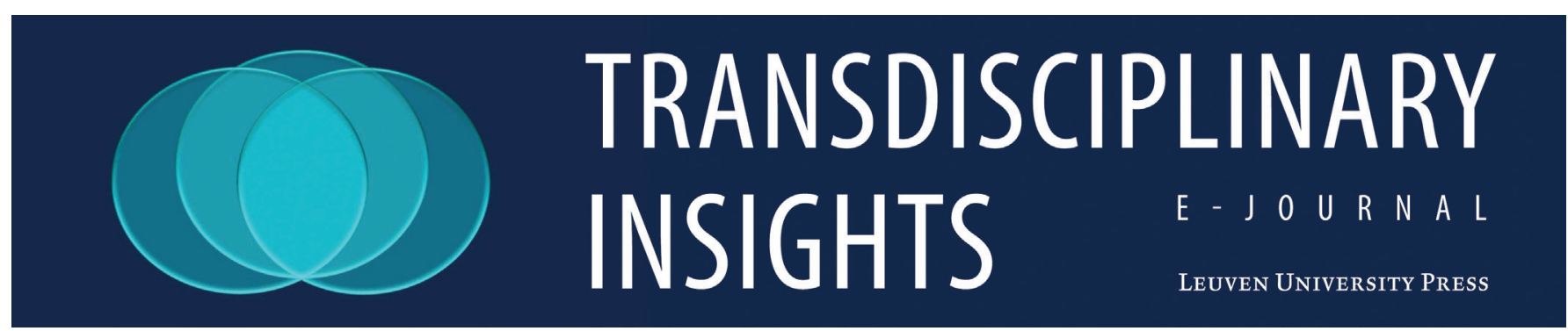

\title{
Prosumers Everywhere: Investigating the Driving Forces Behind Prosumer Behavior in Different Socioeconomic Strata
}

Faysal El Mahmoudi, ${ }^{1,2^{*}}$ Julie Gaillard,,$^{1,3^{*}}$ Mante Hendrickx, ${ }^{1,4^{*}}$ Hyoung Min Suh, ${ }^{1,5^{*}}$

Reine Spiessens, ${ }^{1,6}$ Anne-Mieke Vandamme, ${ }^{7,8, \$}$ Jorge Ricardo Nova Blanco, ${ }^{1,7}$ Astrid Van den Eede ${ }^{1}$

${ }^{1} \mathrm{KU}$ Leuven, Honours Programme Transdisciplinary Insights, Institute for the Future, Leuven, Belgium;

${ }^{2} \mathrm{KU}$ Leuven, Master's student Biochemistry \& Biotechnology, Leuven;

${ }^{3} \mathrm{KU}$ Leuven, Master's student Bioscience engineering, Leuven;

${ }^{4} \mathrm{KU}$ Leuven, Master's student Organizational Psychology, Leuven;

${ }^{5} \mathrm{KU}$ Leuven, Bachelor's student Engineering Technology, Leuven;

${ }^{6} \mathrm{KU}$ Leuven, Master's student Biology, Leuven;

${ }^{7} \mathrm{KU}$ Leuven, Department of Microbiology, Immunology \& Transplantation, Rega Institute for Medical Research, Clinical and Epidemiological Virology, Institute for the Future, Leuven, Belgium;

${ }^{8}$ Center for Global Health and Tropical Medicine, Unidade de Microbiologia, Instituto de Higiene e Medicina Tropical, Universidade Nova de Lisboa, Lisbon, Portugal;

*authors contributed equally

\$Email: annemie.vandamme@kuleuven.be

\section{Abstract}

A systematic change towards a circular economy can alleviate some of the problems associated with today's linear economy, such as pollution. In a circular economy products are recycled, repurposed, re-manufactured, re-used, repaired, and upcycled, thereby minimizing the use of materials, devaluation of products, and output of waste. This requires that producers change manufacturing and design, whilst consumers become 'prosumers', more actively involved in prolonging the life cycle of products through applying methods like repair and re-use.

The consumer to prosumer change is urgently needed, given the current climate and pollution problems. To explore this wicked problem and identify how such a change in behavior can be accelerated a transdisciplinary approach is needed. Therefore, a team of students from different disciplines joined forces, engaging stakeholders with various domains of expertise in and outside the context of the city of Leuven. The need arose for more knowledge about prosumer behavior within the diverse population groups in Leuven, and the team focused on the possible relationship between socioeconomic status and certain reasons for prosuming. It felt that the growth model of the linear economy, aiming at increasing consumption, in the context of a growing world population that strives for welfare, is also indirectly related to social inequality. A questionnaire was created together with several stakeholders asking about socioeconomic status, drivers for prosumption more specifically necessity, information, and awareness - and perceived downsides to prosumption, aimed at the clients of a second-hand store in Leuven. A similar 
questionnaire can be used at other circular economy hot spots in the city, to collect a broad database of responses.

The key to facilitating a transition is to change the behavior, mindset, and attitudes of consumers. The questionnaire was intended to generate a better understanding of why people prosume in certain conditions, and the team assumed this will allow to develop strategies to encourage people to act as prosumers.

\section{Key words}

Circular economy, prosumer, pro-environmental behavior

\section{Introduction}

\section{Challenge statement}

This paper is the result of the work of a team consisting of 5 students, their coaches, and stakeholders. They worked on a challenge from Transdisciplinary Insights, an Honors Program allowing students to tackle problems in a transdisciplinary manner (TDI, https:// rega.kuleuven.be/tdi). The challenge concerned drivers for prosumer behavior in the context of a circular economy in the city of Leuven. The challenge document argues that the throw-away economy not only confines consumers to the role of passive users but also limits the circulation of products within the economic value chain. The transition towards a circular economy requires multiple stakeholders to be engaged. Shifting consumers toward prosumers involves systemic and behavioral changes. These changes are known to be slowed down by structural inertia such as consumer habits and stakeholder immobility. However, there are forces that can accelerate the transition.

The challenge is to understand the dynamics for such systemic changes in the lifestyles of consumers, discovering and understanding the pro-environmental behavior and day-to-day decision processes of Leuvenbased stakeholders. The challenge was submitted by one of the stakeholders, "Maakbaar Leuven" (https:// www.maakbaarleuven.be/), a new organization at the core of a broad circular economic ecosystem. The submitted challenge document is added as suppl 1 .

\section{Concepts}

We define here the concepts in the way they were used during the research process:
"Consumer". "A consumer is a person or organization that uses economic services or commodities" Within the context of economies and marketing a person or organization pays to consume goods and services. The consumer is the end user in the chain of distribution (Cross, 1997).

"Prosumer". The word "Prosumer" combines the words "Production" and "Consumer." The "prosumer" influences the products created, and actively participates in keeping products in the highest value form for as long as possible. (Gunelius, 2010; Scammell, 2003, Blättel-Mink \& Hellmann, 2010).

"Circular Economy". "A circular economy is one that is restorative and regenerative by design and aims to keep products, components, and materials at their highest utility and value at all times (VITO, 2019).

\section{Prosumers in a circular economy}

Our current economic system is thresspassing the limits of our planet. The planet's resources are becoming more and more scarce as the population's material consumption and the population itself increase (Jackson, 2011). Next to this, climate and pollution problems caused by the consumption and production of products and materials are harming natural ecosystems including the one we live in. Therefore, an alternative economic system is urgently needed in which economic development is decoupled from linear production practices through the circulating of materials and products that are already present in the ecosystem. This alternative economic system, known as the circular economy ( $C E$ ), is a system where products and materials are kept at their maximum value and functionality for as long as possible (VITO, 2019). This is contrary to the traditional economic system where the used material is discarded as waste to be burned or dumped (Ellen MacArthur Foundation, 2013). In these final steps the products and materials not only immediately reach their lowest possible values to society but also directly add to climate and pollution problems. An active consumer can save used materials from the waste stream by giving them a second lifecycle. This can, for example, be done by repairing and/or reselling used items. In this cycling of products the value is kept relatively high. This way the product can still add value to society and contribute to GDP growth. These active consumers are called prosumers, and increasing their presence in our society can contribute to increased 
welfare in all layers of society and circumvent the environmental problems of the traditional linear system. However, as stated in the challenge document, structural inertia such as consumer habits and stakeholder immobility can inhibit the proper functioning of the circular economy and prosumer behavior (suppl 1).

\section{How to become a prosumer}

The scheme in Figure 1 demonstrates the differences and interactions of the circular economy vs the traditional economy. It also shows the different ways in which a prosumer can give a second life to products and materials. When starting from the bottom, a consumer can become a prosumer by repairing or repurposing a certain product. The consumer can also return the product to the original store, whereupon the product can be resold. However, since not many stores offer this service, this has led to the rise of secondhand stores where products can be resold regardless of their origin. A product does not need to be sold, but can also be given to a person in need of it and so be given a second life. Those cycles usually do not exclude each other but can be found in different combinations and interactions. In the outer two circles, the product can be repurposed, remanufactured, or recycled, but since those extensions are rather too technical for a general consumer, thus not well suited for prosumer behavior, they are considered less important for this research and will therefore not be mentioned again.

\section{Socioeconomic context}

Some driving factors that impact the way consumers may engage in more prosumer behavior relate to differences in socioeconomic classes, since different environments created by differences in social classes lead to different needs and expectations. For example, a rich person owns some "positional goods" (e.g. branded clothes or clothes in excess of what is strictly necessary) in order to flaunt his socioeconomic "position" to others. Usually these goods will be bought new as rich people can afford it. A poorer person, however, may lack the financial resources to buy such a product new and will have to repair an old one, or buy it second hand. Even for "necessity goods" (e.g. baby clothes) prosumer behavior differs among socioeconomic classes. This way the driving forces will change according to the prosumer's position on the

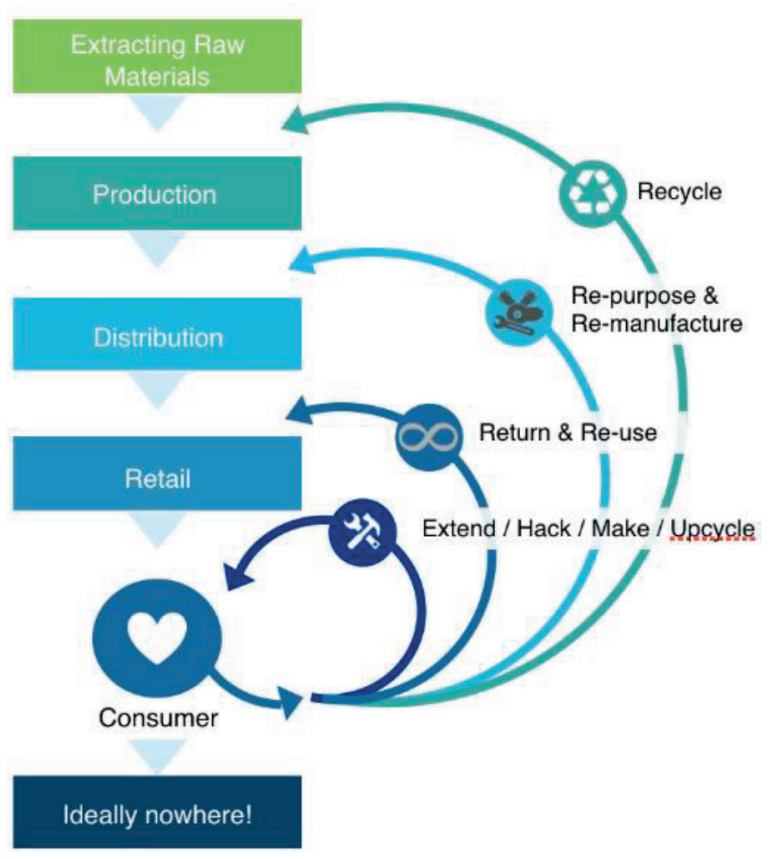

Figure 1. Scheme of the circular economy (IBM, 2019) (Graph reproduced with permission from Eva Heukäufer and IBM)

socioeconomic ladder. The questionnaire is mainly targeted at the socio-economically disadvantaged stratum of the Leuven population, up to the middle class, hereby excluding the rich upper class. It tries to solicit answers by which one could identify how the driving forces change according to socioeconomic class in order to find different strategies to make prosumer behavior more attractive for different target populations originating from different socioeconomic classes.

\section{Hypothesis and research question}

Prosumer behavior is already present in the lifestyles of the economically disadvantaged population of our society out of necessity. However, prosumer behavior may transform into general consumer behavior when the economically disadvantaged person escapes poverty. On the other hand, information and awareness about the negative sides of general consumer behavior and the positive sides of prosumer behavior could transform a consumer into prosumer, or prevent a prosumer changing into a consumer when rising in social class. It is unclear whether information and awareness are sufficient as drivers to instigate prosumer behavior, or whether other drivers also play a crucial role. We believe that developing a questionnaire that probes these drivers is a step in the right direction. 


\section{Methods}

\section{Research process}

\section{Assumption analysis}

During the planning phase of our project we analyzed the assumptions set out in the challenge document. This part of the process was essential to minimize the risk of building a project based on wrong assumptions. The analysis took place during meetings where team members identified all the assumptions, and on a one by one basis explicitly stated what the inaccuracies or inconsistencies of the assumption were, based on information gathered in the literature. In the cases where the assumption was not deemed well grounded, additional research was needed in order for us to understand the assumptions in the context of our project that was being developed.

\section{Three types of knowledge}

The team followed the ten steps of transdisciplinary research (Pohl, 2017) in which they reflected on the three types of knowledge. In this step recent publications on circular economy and pro-environmental behavior were studied (state of the art literature review) in order to form new insights and identify knowledge gaps needed to develop strategies to increase prosumer behavior in the city of Leuven.

\section{Actor constellation}

In addition to the assumption analysis an actor constellation exercise was needed to identify implicit biases on each actor's relevance to the project. The team identified actors, labeled local and external stakeholders of the circular economy in Leuven, and jointly decided on an adequate position. The perceived contribution of an actor to the project was expressed as the distance at which the actor was placed from the research question at the center. The actors with the highest stakes were placed closer to the center, while actors with less importance were placed further away from the center of the map.

\section{Stakeholder Meetings}

During a stakeholder meeting organized by maakbaar Leuven, the team had the opportunity to discover and interview many of the stakeholders of circular economy in Leuven. The stakeholders were asked to explain the services and products they provide, where they are situated in the city, and what their target population is in order to gain more insights into the current state of prosumer behavior in Leuven.

\section{Results}

To explore the wicked problem of changing consumers' behavior to becoming prosumers a transdisciplinary approach is needed, using as its definition the one from the Institute for the Future (https://rega.kuleuven. be/tdi/Home). A team of students from different disciplines (see author list) joined forces, and together performed the assumption analysis, reflected on the three types of knowledge, and performed the actor constellation exercise. They then engaged with stakeholders to try to include their view in the research process.

The assumption that changing the behavior, mindsets, and attitudes of actors in the circular economy was the key to making the transition from consumers to prosumers happen laid the foundation of our hypothesis. This assumption implies that the challenge of the project lies in understanding the conditions and drivers of consumers in regard to dealing with the life cycles of consumer goods.

In the context of the three types of knowledge, to check the current state of driving forces towards circular economy and prosumer behavior in society a literature research was performed using LIMO and Google Scholar. The main focus was put on the most recent articles. The first key word was 'Circular Economy' and led to four useful articles (Table 1). However, only the last two articles mentioned driving forces or barriers to changing consumer behavior. Second, the word 'Prosumer' was searched, but this word did not lead to relevant scientific papers on the topic in the way the word is used in this research. Since more information was needed on drivers toward behavioral change the key phrase 'behavioral change' was added. This led to finding the first source mentioned in the list regarding pro-environmental behavior. Since this seemed to be a relevant article on the subject of 'driving forces towards behavior change', we went deeper into the sources used for this article and the eight most relevant sources were used and served as inspiration for our research. Afterwards, we also found an article on sustainable 
Transdisciplinary Insights Volume 3, 2019, 198-218.

Leuven University Press, Online ISSN 2593-0338

https://doi.org/10.11116/TDI2019.3.8

Table 1. List of article titles that were collected for the literature study.

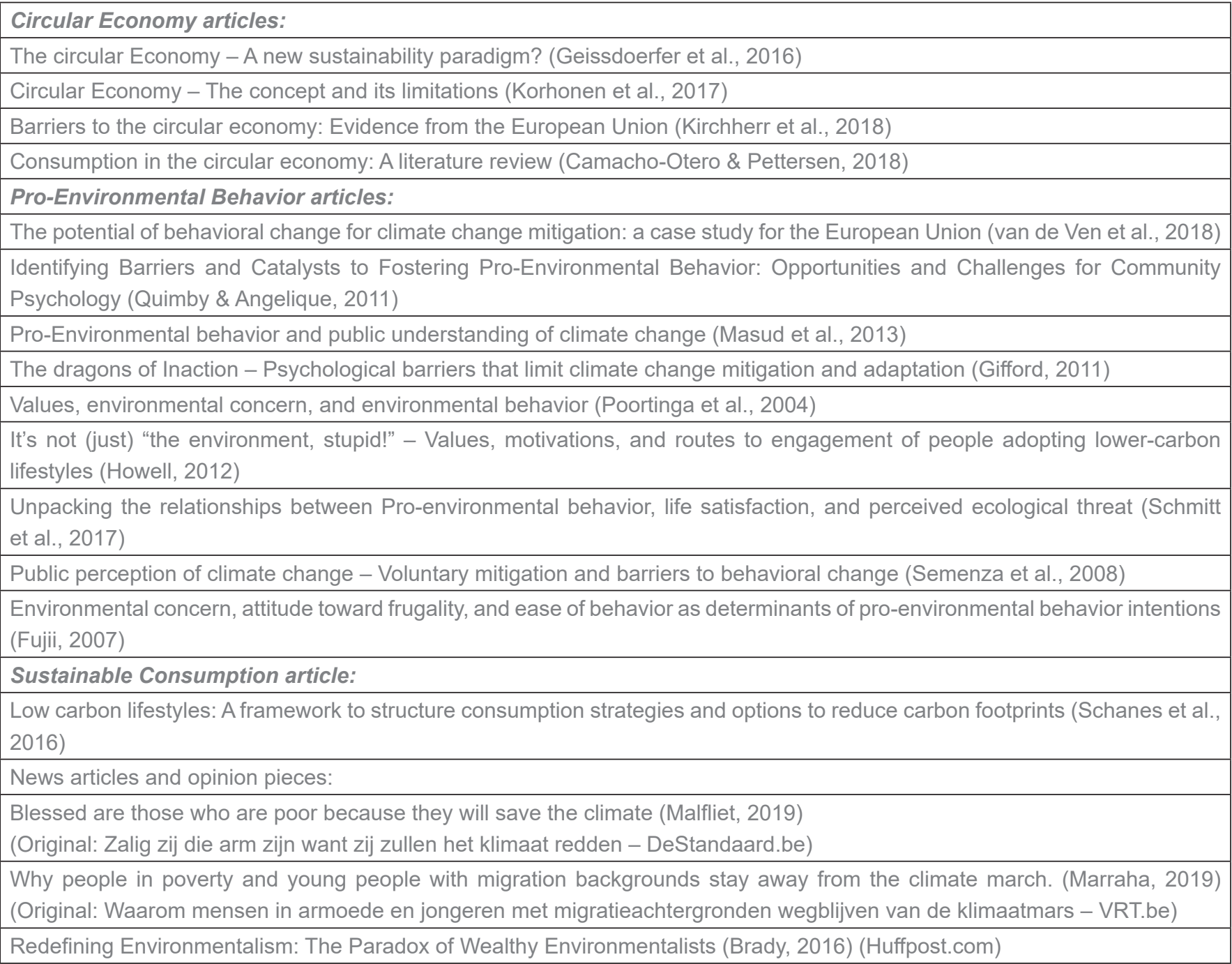

consumption leading to low carbon lifestyles using the key word 'Sustainable consumption'. However, next to this some non-scientific articles also caught our eye during the research in the form of news articles and opinion pieces. Those articles mentioned the presence of low-carbon lifestyles in the poorer strata of society, whereas the scientific papers on circular economy and PEB did not mention this aspect.

Performing the actor constellation allowed us to form a representation of what we thought the important actors were. A subsequent stakeholder meeting allowed us to interpret the representation of actors in the Leuven prosumer ecosystem. This stakeholder meet-up, organized by Maakbaar Leuven, allowed us to interview individuals and organizations involved with the repair economy in the Leuven ecosystem. We compiled a list of the interactions we had and located them on a physical map of Leuven. We subsequently used this information and repeated the actor constellation exercise to get a better idea of how the activities of certain stakeholders are linked (Fig. 2). We concluded that there are multiple important connection hubs (local communities, second-hand stores) where the repair economy plays an important role. This observation pushed us forward to further question, without assumptions, what the underlying drivers were of the prosumers involved within these interconnected hubs.

Based on a talk during the stakeholder meeting with a representative of an organization offering circular economy tools to poorer parts of society and based on the news articles and opinion pieces found in the literature research, we concluded that there was a strong representation of actors and stakeholders that focused on facilitating and enabling prosumer behavior in the 


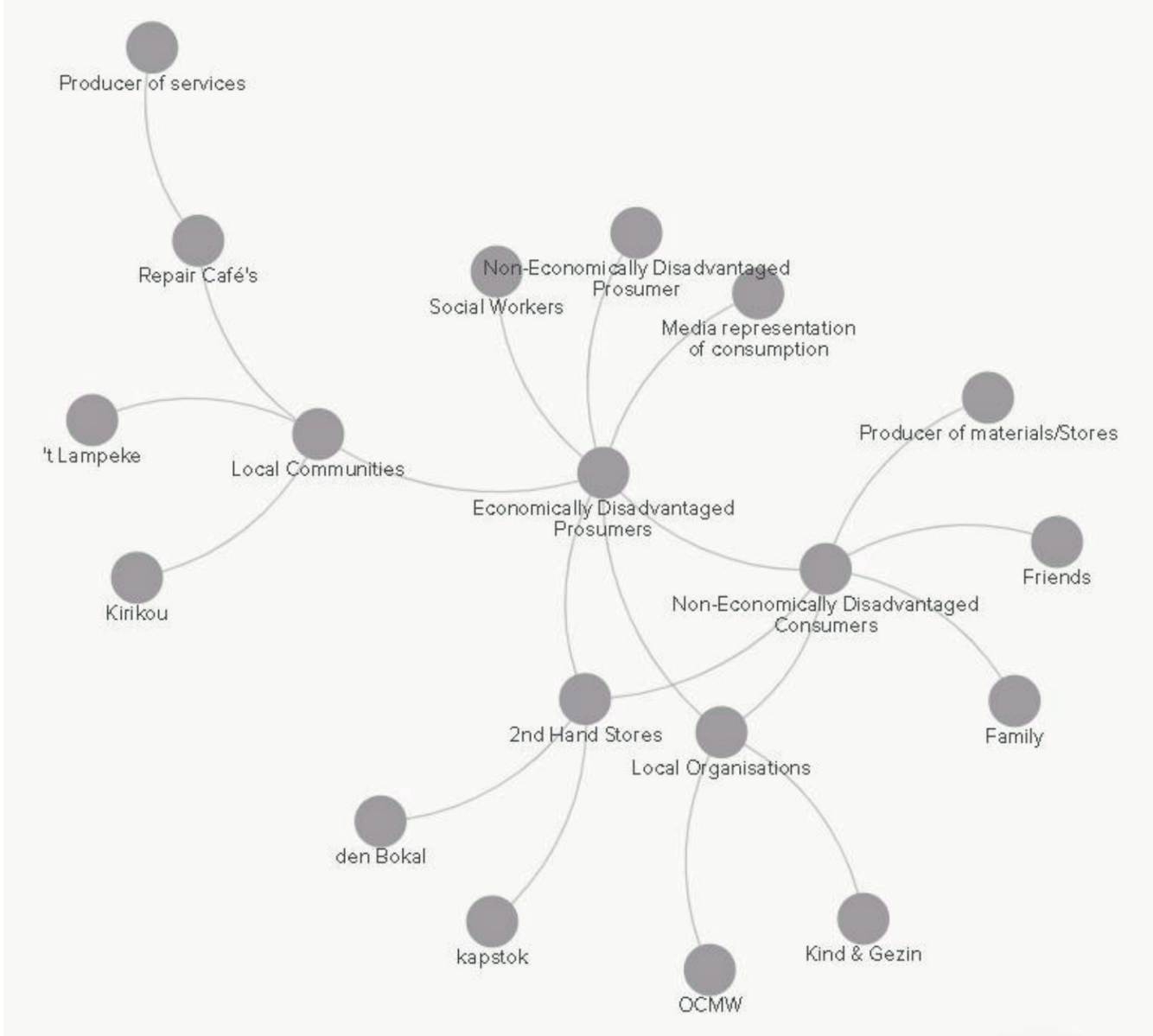

Figure 2. Result from the actor constellation exercise. The actors represented here are those we met during a stakeholder meeting in Leuven organized by Maakbaar Leuven (see text).

socio-economically disadvantaged stratum, followed by the middle class consumers that were already participating in more active and pro-environmental behavior.

However, by reflecting on the three types of knowledge, the team found that the literature generally did not study the presence of circular economy tools or pro-environmental behavior in the poor classes of society, but focused more on the reasons for the absence of circular economy and pro-environmental behavior in the middle class (Kircher et el., 2018; Camacho-Otero \& Pettersen, 2018). When the authors of those publications examine the 'barriers', 'catalysts', or 'driving forces', they usually do not link the findings to socioeconomic class (van de Ven et al., 2018; Quimby \& Angelique, 2011; Masud et al., 2013; Gifford, 2011; Poortinga et al., 2004; Howell, 2012; Schmitt et al., 2017; Semenza et al., 2008; Fujii, 2007). Repeating the literature search in Web of Science and Environmental Innovation and Societal Transitions and Nature Climate Change using "'socio-economic status"
AND behavior; "economic status" AND behavior AND consumer; did not result in more relevant literature and revealed that most studies focused more on the relationship between circular behavior and attitude toward climate and the general sustainability transition mechanism and the reasons for the absence of proenvironmental behavior.

This way they not only miss the fact that the driving forces can change depending on where a person finds $\mathrm{him} /$ herself on the socioeconomic ladder, but also miss why circular economy and pro-environmental behavior can be attractive in some situations.

The need for more knowledge about prosumer behavior within the diverse population groups of Leuven arose, and the team focused on the possible relationship between socioeconomic status and certain reasons for prosuming. It felt that the growth model of the linear economy, aiming at increasing consumption, in the context of a growing world population that strives for welfare is also indirectly related to social inequality. The 
insights we gained from the above-mentioned processes pointed us in the direction of developing a tool that might deliver us valuable information about driving forces of prosumer behavior and its relationship to socioeconomic status.

Based on our literature research, we found our line of research to be new in the sense that behavior change is investigated in relation to socioeconomic circumstances. We wanted to investigate whether there is a relation between socioeconomic class and the driving forces of behavior change of the general consumer who transitions into prosumer, and whether there might be differences with respect to the driving forces related to pro-environmental behavior.

The team opted to develop a questionnaire for various reasons (Suppl 2). Questionnaires can be filled in using an electronic device present on site, making it easily accessible, efficient, and cost-friendly to gather information quickly (Neckebroeck et al. 2018). The gathered information can be transformed into numeric data, which makes it possible to compare different response rates for each answer and statistically analyze the responses, such as determining correlations between responses from different questions. It also allows us to generalize the findings for the entire target population if the sample is representative. We communicated our insights to the public during a symposium (Suppl 3).

A questionnaire can be used to probe whether or not prosumer behavior was (1) based on necessity since prosumer behavior is often cheaper and can therefore lead to monetary savings; (2) based on information and awareness, where the knowledge of the societal costs of general consumer behavior acts as a driver; or (3) based on another driver. Such a questionnaire enables us to relate the answers on driving forces to information about the socioeconomic status of the respondents. This knowledge can then lead to a better understanding of what the main driving forces are that make people exhibit prosumer behavior in each layer of society and if and why these motivations change with social status mobility. It also allows us to develop different strategies in cooperation with stakeholders to change the mindset, attitude, and behavior of consumers in order for them to act as prosumers.

A questionnaire was created based on our interactions with several stakeholders asking about socioeconomic status, drivers for prosumption - more specifically necessity, information, and awareness - and perceived downsides to prosumption, aimed at the clients of a second-hand store in Leuven. We went through an iterative process during the development of our questionnaire, speaking with stakeholders, experts, and citizens, where at each step incremental improvements to the questionnaire were made. A similar questionnaire can be used at other circular economy hot spots in the city to collect a broad database of responses.

Our questionnaire contains two questions that probe qualitative aspects of prosumer behavior (Suppl 2, question 6 and 7 of the $2^{\text {nd }}$ group). The main benefit of questions in free format that can be used for qualitative research is that additional information can be captured that might have been lost with a purely quantitative approach. It is an opportunity to further characterize certain motivations of people. Since quantitative and qualitative research are complementary to each other, combining both into one questionnaire gives us the opportunity to combine the benefits of both types and minimize the drawbacks of using only one type.

To gather the information, random people on site at organizations offering prosumer tools or services in Leuven, e.g. the 'SPIT' second-hand store in Leuven, can be interviewed in a systematic way using this questionnaire. The questionnaire contains mainly multiple-choice questions (for quantitative analysis) and two open questions (for qualitative analysis). This resulted in a questionnaire containing 18 questions divided into three groups; 16 are multiple choice, and two are open questions. Every group of questions investigates one driving factor. The first group investigates the socioeconomic status of the respondent in six questions. The second group explores the respondent's need for the tool/service in nine questions, where it also asks about the advantages and disadvantages of the tool/service in open questions. The last group containes four questions that probe whether the respondent is concerned with ecology and sustainability and whether people in his/her environment support the prosumer behavior or not. The collection of responses of the survey could result in a broad database that can be further analyzed.

\section{Discussion}

In an iterative process following feedback from stakeholders, our research aimed to develop a useful questionnaire that can probe the drivers of specific 
participants in the circular economy. With this questionnaire we wanted to probe the validity of our hypothesis, which stated that multiple drivers might contribute to prosumer behavior, more specifically necessity, information, and awareness and socioeconomic status. We intended to develop a set of questions that can characterize each of these drivers as accurately as possible.

Many aspects determine the efficacy of the questionnaire. The types of questions we decide to ask, how they are formulated, the order in which they are presented, the length of the survey, the medium used, and where the survey is conducted all have to be taken into account since all of them have an influence on the result. We designed our questionnaire around the idea of making it accessible and approachable for people from all walks of life. The questionnaire is meant to be deployed at various "prosumer hotspots", such as repair cafés, thrift stores etc. where we can gauge which parameters we need to tweak in response to user feedback. Optimizing the questionnaire for different target audiences will be an ongoing task and is part of a continued iterative process and design.

Trying to understand why certain actors exhibit specific behavior is not an easy endeavor. The current version of the questionnaire is limited by the scope of the three drivers that are being probed. Having too broad a scope would hamper the resolution of each driver. Relating the interacting drivers to the observed behavior would not be possible with too narrow a scope. We argue that developing sets of questions for a limited group of drivers at a time is the compromise that makes the most sense.

\section{Conclusion}

We have combined and illustrated the information acquired from assumption analysis, literature research, actor constellation exercise, stakeholder interviews, and iterative feedback sessions. We constructed guidelines for the questionnaire in agreement with research interests and boundaries. These discussions led us to kickstart the development of a questionnaire designed to probe specific drivers related to prosumer behavior, and more specifically how these drivers might change in different socioeconomic strata. We assume that a better understanding of why people prosume in certain conditions could help in the process of developing strategies to encourage people to act as prosumers.
The development of the questionnaire is an ongoing and iterative process where feedback from stakeholders has to be incorporated. Our questionnaire went through one such cycle after direct communication with SpiT (the second-hand store in Leuven), asking its opinion about the questionnaire and whether or not we could eventually deploy it in one of its stores. Its input and cooperation proved to be very valuable in optimizing our questions based on its experiences. Due to time constraints, we could not involve the stakeholders as intensively as we had wanted, given that we were aiming at a transdisciplinary effort.

The addition of a complementary questionnaire that probes the drivers of actors that function as "employees" at organizations that are set up at prosumer hotspots would allow future researchers to better understand the dynamics of the whole prosumer ecosystem. The questionnaire we delivered is still a work-in-progress and still requires multiple cycles of optimization which should be the result of further direct communication with stakeholders, sharing their experiences, and potential feedback from the prosumers contributing to that specific organization.

We believe that a bottom-up approach toward strategies that promote prosumer behavior and prosumer drivers of the actors is a powerful but at the same time practical approach.

\section{Acknowledgements}

We want to thank all contributors that helped in sharing their knowledge along the process of writing this paper. Special thanks go to Jan Larosse and Erik Baetse for coaching us and bringing us into contact with multiple stakeholders in Leuven.

\section{Supplementary Material}

1. The Original Challenge Document

2. The Questionaire, in Dutch and English

3. Video of the presentation at the symposium "KU Leuven facing the future", May 8, 2019, Leuven, Belgium.

\section{Literature}

Blättel-Mink, B., Hellmann, K.-U. (2010). Prosumer Revisited: Zur Aktualität einer Debatte. Springer.

Brady, Aletta (Member, U. S. N. C. to U. Y. W. G. (2019). Redefining Environmentalism: The Paradox of 
Wealthy Environmentalists. Huffpost. Retrieved from https://www.huffpost.com/entry/redefiningenvironmentali_b_9636552

Camacho-Otero, J., Boks, C., \& Pettersen, I. N. (2018). Consumption in the circular economy: A literature review. Sustainability (Switzerland), 10(8). https://doi. org/10.3390/su10082758

Cross, Robert G. (1997). Revenue management: hardcore tactics for market domination. Broadway Books. pp. 66-71. ISBN 978-0-553-06734-7.

Ellen MacArthur Foundation 2013. Founding Partners of the Ellen MacArthur Foundation. (2013). Circular economy towards the economic and business rationale for an accelerated transition. P24. Retrieved from https://www.ellenmacarthurfoundation.org/assets/ downloads/publications/Ellen-MacArthur-FoundationTowards-the-Circular-Economy-vol.1.pdf

Fujii, S. (2006). Environmental concern, attitude toward frugality, and ease of behavior as determinants of pro-environmental behavior intentions. Journal of Environmental Psychology, 26(4), 262-268. https:// doi.org/10.1016/j.jenvp.2006.09.003

Geissdoerfer, M., Savaget, P., Bocken, N. M. P., \& Hultink, E. J. (2017, February 1). The Circular Economy - A new sustainability paradigm? Journal of Cleaner Production. Elsevier Ltd. https://doi.org/10.1016/j. jclepro.2016.12.048

Gifford, R. (2011). The Dragons of Inaction: Psychological Barriers That Limit Climate Change Mitigation and Adaptation. American Psychologist, 66(4), 290-302. https://doi.org/10.1037/a0023566

Gunelius, S. (2010). The Shift from CONsumers to PROsumers. Retrieved July 1, 2019, from http://www. forbes.com/sites/work-in-progress/2010/07/03/ the-shift-from-consumers-to-prosumers/

Howell, R. A. (2013). It's not (just) "the environment, stupid!" Values, motivations, and routes to engagement of people adopting lower-carbon lifestyles. Global Environmental Change, 23(1), 281-290. https://doi.org/10.1016/j.gloenvcha.2012.10.015

IBM Consumer Products Industry Blog. (n.d.) Circular Economy - 'Like a circle in a spiral'. Retrieved July 1, 2019, from https://www.ibm.com/blogs/insights-onbusiness/consumer-products/like-a-circle-in-a-spiral/

Jackson, T. (2011). Confronting consumption: challenges for economics and for policy. In S Dietz, J Michie and C Oughton (Eds) The Political Economy of the Environment: an Interdisciplinary approach: 189-212. Abingdon and New York: Routledge.

Kirchherr, J., Piscicelli, L., Bour, R., Kostense-Smit, E., Muller, J., Huibrechtse-Truijens, A., \& Hekkert, M. (2018). Barriers to the Circular Economy: Evidence From the European Union (EU). Ecological
Economics, 150, 264-272. https://doi.org/10.1016/j. ecolecon.2018.04.028

Korhonen, J., Honkasalo, A., \& Seppälä, J. (2018). Circular Economy: The Concept and its Limitations. Ecological Economics, 143, 37-46. https://doi.org/10. 1016/j.ecolecon.2017.06.041

Malfliet, G. (2019). Zalig zij die arm zijn, want zij zullen het klimaat redden. ATD Vierde Wereld België. Retrieved fromhttp://atd-vierdewereld.be/opiniestuk-zalig-zij-diearm-zijn-want-zij-zullen-het-klimaat-redden/

Marraha, I. (2019). Waarom mensen in armoede en jongeren met migratieachtergrond wegblijven van de klimaatmars. VRT. Retrieved from https://www.vrt.be/ vrtnws/nl/2019/01/29/klimaatmars-is-niet-vooriedereen/

Masud, M. M., Akhtar, R., Afroz, R., Al-Amin, A. Q., \& Kari, F. B. (2015). Pro-environmental behavior and public understanding of climate change. Mitigation and Adaptation Strategies for Global Change, 20(4), 591600. https://doi.org/10.1007/s11027-013-9509-4

Neckebroeck, C., Vanderstraeten, I., \& Verhaeghe, M. (2018). Onderzoeksvaardigheden: Voor onderwijs, zorg en welzijn (2de editie ed.). Wommelgem: Van In.

Netwerk Bewust Verbruiken. (n.d.). Wat is de ecologische voetafdruk? Retrieved July 1, 2019, from https://www. bewustverbruiken.be/artikel/wat-de-ecologischevoetafdruk

Pohl, C., Krutli, P., \& Stauffacher, M. (2017). Ten reflective steps for rendering research societally relevant: While the goal of transdisciplinary research is to be relevant to society, specific instructions for accomplishing this remain implicit. We propose to improve this situation by means of a 10-step approach aimed at stimulating explicit reflections around ways to render research more societally relevant. GAIA - Ecological Perspectives for Science and Society, 26(1), 43-51. https:// doi.org/10.14512/gaia.26.1.10

Poortinga, W., Steg, L., \& Vlek, C. (2004). Values, environmental concern, and environmental behavior: A study into household energy use. Environment and Behavior, 36(1),70-93.https://doi.org/10.1177/001391 6503251466

Quimby, C. C., \& Angelique, H. (2011). Identifying Barriers and Catalysts to Fostering Pro-Environmental Behavior: Opportunities and Challenges for Community Psychology. American Journal of Community Psychology, 47 (3-4), 388-396. https://doi.org/10.1007/s10464-010-9389-7

Scammell, M. (2003). Citizen Consumers: towards a new marketing of politics? Retrieved from https://depts. washington.edu/gcp/pdf/citizenconsumers.pdf

Schanes, K., Giljum, S., \& Hertwich, E. (2016). Low carbon lifestyles: A framework to structure consumption strategies and options to reduce carbon footprints. 
Journal of Cleaner Production, 139, 1033-1043. https://doi.org/10.1016/j.jclepro.2016.08.154

Schmitt, M. T., Aknin, L. B., Axsen, J., \& Shwom, R. L. (2018). Unpacking the Relationships Between Proenvironmental Behavior, Life Satisfaction, and Perceived Ecological Threat. Ecological Economics, 143, 130140. https://doi.org/10.1016/j.ecolecon.2017.07.007

Semenza, J. C., Hall, D. E., Wilson, D. J., Bontempo, B. D., Sailor, D. J., \& George, L. A. (2008). Public Perception of Climate Change. Voluntary Mitigation and Barriers to Behavior Change. American Journal of Preventive Medicine, 35(5), 479-487. https://doi. org/10.1016/j.amepre.2008.08.020
Transdisciplinary Insights - Honours Programme | Rega Instituut KU Leuven . (n.d.). Retrieved July 1, 2019, from https://rega.kuleuven.be/tdi

van de Ven, D. J., González-Eguino, M., \& Arto, I. (2018). The potential of behavioural change for climate change mitigation: a case study for the European Union. Mitigation and Adaptation Strategies for Global Change,23(6),853-886.https://doi.org/10.1007/s11027017-9763-y

VITO 2019. What is a circular economy | VITO. (n.d.). Retrieved July 1, 2019, from https://vito.be/en/circulareconomy/what-circular-economy 


\section{Supplement 1: The Original Challenge Document}

\section{BANK OF TRANSDISCIPLINARY CHALLENGES \\ HONOURS PROGRAMME TRANSDISCIPLINARY INSIGHTS}

\section{NAME OF THE CHALLENGE}

How can citizens in Leuven become 'prosumers' in giving a second life to discarded or broken things?

\section{Proposed title}

From consumers to prosumers: reducing waste and extending sustainable use of consumer products in Leuven by repair and other strategies.

\section{Main coach:}

Jan Larosse/Erik Beatse, manager Maakbaar Leuven

\section{Supporting coach}

\section{Prof Karel Van Acker}

\section{Key words}

Circular economy/transition/consumer-driven/prosumer/repair/Leuven Living-Lab/accelerated obsolescence/ citizen science/action research/repair commons/decision making support/data/on-demand spare parts/new business models/taking care of things

Could you please state a specific challenge, problem, or question? If you have more than one challenge, please submit each challenge separately. Please be aware that if the same or a very similar challenge is submitted by multiple actors, we will pool this into a single challenge, and as a result the challenge might diverge slightly from what you submitted.

The transition towards a circular economy is a structural change in the organization of material flows (from linear to closed loop, and from flows to stocks), but even more in the organization of economic interactions between producers and consumers. In a consumerist 'throw-away' economy the consumer is limited to the role of a passive user, to which a producer wants to sell as many products as possible. But in a circular economy this consumer will become a more active user who takes care of products in their life cycle, and is encouraged to give them a second life if possible. The evolution of consumer to 'prosumer' (including production activities to assemble, maintain, repair, even co-design) has multiple levers, but the enhanced consumer function in a circular economy is a major one.

The circular economy transition is a process that is slowed down by structural inertia (such as built-in obsolescence in products and consumerism). But there is an urgency to accelerate these transformations because of the impact of materials extraction and waste production on climate change. The adoption of new business models for circular economy such as leasing, that gives all product liability to the producers, can have the disadvantage of maintaining consumers in a passive role instead of mobilizing their creative energy as prosumers. An important lever for change is the position of the consumer of a product as a citizen in a community. His experience with sustainability issues at city level can influence new attitudes. The challenge therefore is to understand better the conditions for systemic changes in the daily life of consumers, dealing with matters of 'life or death' of consumer goods. Concretely: How can citizens in Leuven become 'prosumers' in giving a second life to discarded or broken things? 
Would you like to add some objectives to that challenge? For example, can you imagine how you want the future to be with regard to this specific challenge? Is there any specific result that you want the research group to reach?

The question is how citizens in day-to-day decision processes for disposal or renewal of consumer goods can adopt more sustainable alternatives such as shared use and repair. What are the drivers for consumers to behave as 'prosumers' and as 'citizens' when making decisions related to consumer goods (and to act accordingly). Some case-studies can be instrumental for this: on electrical devices, on building material, on pharmaceuticals.

Action research on citizen-driven transition activities towards the circular economy should be solution driven. What can work? The practice of Maakbaar Leuven can be a reference. Maakbaar Leuven is a social innovation practice for building a repair ecosystem, using the repair commons as lever.

Indicators on the volume and effects of the repair economy are difficult to define, since a big part is informal economy. However, it is clear that the project finally aims at a considerable increase in the life of consumer goods, and hence a reduction in environmental impact and resource consumption.

The challenge is to discover a common (cross)disciplinary approach that enriches our understanding of prosumer behavior and its activation in a 'Leuven living lab' context. How can citizens in Leuven become 'prosumers' in giving a second life to discarded or broken things?

\section{Could you please let us know the context of the challenge and why you think this challenge is relevant to a transdisciplinary research team? Please be aware that our transdisciplinary research teams accept only chal- lenges that have to be dealt with from different points of view.}

In order to answer such challenge for structural change in consumer behavior towards 'prosumer' behavior a multi-disciplinary research approach needed to be developed, including explorative and action research with consumer involvement (citizen science). But to lay the ground of such an integrated approach better understanding of the context of this behavioral change is required:

- What are the structural barriers that in the first place make the average life of products decrease ever more and that limit the role of consumers (information and expertise)?

- What are the specific conditions of daily decision making in Leuven households? I.e.: which are the problems in different categories of things that are broken, worn out, unused; which things are more vulnerable; which solutions are available and how can they be shared in the community?

- What is the present market for repair and re-use services?

- What is the role of new technologies like 3D printing to provide on-demand repair components?

- Which regulations are influencing the design for longer life, repairability, and re-use? What are the legal issues (like liability for repair)?

After stock-taking of what knowledge already exists and what the opportunities for new approaches are, the research will identify the domains, topics, action lines where research can make a difference in accelerating the pace of transition to a new circular economy agency, focusing on prosumer behavior. The focus on the prosumer as agent is studying not only an economic or sociological phenomenon, but also a political subject. It involves thinking about value creation in a wider (philosophical and ethical) dimension. It is about the role of 'commons' (shared knowledge, expertise, and infrastructure) among prosumers in this transition and the role of IP regulations in this agency. It is about prosumer-friendly product design, technology interfaces, and information platforms. But such study of emergent behavioral patterns is also about capturing data on consumer behavior and early signals of changes (data analytics, pattern recognition). It is about a thing-pedagogy of taking care of things as a medium for self-deployment and social meaning.

The challenge is to discover a common (cross)disciplinary approach that enriches our understanding of prosumer behavior and its activation in a 'Leuven living lab' context. How can citizens in Leuven become 'prosumers' in giving a second life to discarded and broken things? 
Therefore many disciplines can be involved from different science groups that are needed for joint solutions (not limitative):

Humanities and Social Sciences Group:

Business and Economics: New models about value-creation and new business models in the frame of the circular economy

Law: Intellectual property in the framework of the circular Economy and specific legal issues and liabilities (e.g. on recovery of sold but unused pharmaceuticals)

Social Sciences and Psychology: consumer attitudes and social behavior towards the circular economy

Philosophy: to contribute about the philosophical foundations and ethical dimension for the challenge

Biomedical Sciences Group

Medicine: Health risks associated with repair (dangerous materials)

Pharmacology: Risks in disposal of medicines

Rehabilitation: Restoring work-life balance and particular disorders (incl. burn-outs) by DIY

Science, Engineering and Technology Group:

Sustainable development: environmental impact of repair and re-use, impact on resource efficiency

Additive manufacturing: 3D printing as a key function for circular economy

IT Platforms: how to organize repair activities, follow up life-times, share repair information

Waste resources engineering: define the best way to dispose safely of broken parts

Possible partners, experts and/or other stakeholders to involve in this challenge If you want your challenge to be dealt with not only by a transdisciplinary research group but also by stakeholders, could you please suggest stakeholders' name(s) to get involved in this research and, if you have them, some contact details of each one?

Maakbaar Leuven 'Maakbaar Leuven: hier brandt de lamp voor een slimme en circulaire regio!'

Maakbaar Leuven is a new initiative for the promotion of a new repair economy, established on June 21, 2018 in the city of Leuven. It aims at impact at local level with a global vision. It is a partnership of more than 40 organizations that are committed to supporting a sharing platform for repair knowledge, expertise, and infrastructure (such as repair cafés and Fablabs) to enable citizens in the Leuven region to make choices for sustainable repair solutions. This platform is at the core of a broad ecosystem (with 'quadruple helix' approach, involving citizens, research, business, and the public sector in the value chain of repairable goods). The cooperation is based on a Charter and an action plan. 


\section{Supplement 2: The Questionaire in Dutch and English}

\section{DUTCH VERSION}

\section{Circulaire economie in Leuven}

Beste lezer,

Wij zijn vier studenten van KU Leuven die deelnemen aan een onderzoeksproject. Ons onderzoek gaat over circulaire economie en 'prosumenten' in Leuven. Een prosument is een persoon die een product consumeert en produceert. 'Prosumptie' slaat op de praktijk waarbij één persoon bepaalde producten en diensten creëert, en uiteindelijk ook zélf dit product gebruikt. We onderzoeken in ons project hoe men consumenten kan omvormen tot prosumenten, met als doel een meer duurzame en circulaire economie te creëren in Leuven.

We besloten om in ons onderzoek te focussen op het prosumentengedrag bij economisch benadeelde personen in Leuven. Prosumentengedrag is volgens verschillende bronnen reeds aanwezig in de levensstijl van armere personen. Ze repareren vaker hun eigen spullen, lenen dure voorwerpen en gereedschappen en kopen tweedehands om zo dure kosten te vermijden.

Door dit onderzoek willen we te weten komen wat de grootste drijvende krachten zijn die ervoor zorgen dat iemand prosumentengedrag vertoont. Verschilt dit afhankelijk van iemands plaats in de samenleving? Verandert het prosumentengedrag wanneer iemands sociaaleconomische status verandert?

Deelnemers aan dit onderzoek worden willekeurig geselecteerd. We gebruiken verschillende vragenlijsten afhankelijk van het doelpubliek. Zo is er een vragenlijst specifiek voor klanten van de tweedehandswinkel, en één voor de werknemers van de tweedehandswinkel. We hopen aan de hand van deze vragenlijsten informatie te verzamelen waardoor we in de toekomst succesvol consumenten kunnen motiveren om prosument te worden.

De vragenlijst is volledig anoniem. Er zijn geen juiste of foute antwoorden, u kan gewoon antwoorden vanuit uw eigen ervaring. Als u een vraag niet begrijpt, mag u altijd meer uitleg vragen.

Het invullen van de vragenlijst duurt een 5 -tal minuten. Bent u bereid om de vragenlijst in te vullen? Indien u tijdens of na het invullen van de vragenlijst zich bedenkt, kan u steeds stoppen en zeggen dat we jouw antwoorden niet mogen gebruiken in ons onderzoek.

Alvast bedankt en vriendelijke groeten,

Julie, Faysal, Nick en Mante

Er zijn 18 vragen in deze enquête onderverdeeld in 3 groepen.

\section{Status}

In deze vraaggroep willen we graag informatie verzamelen over uw sociaaleconomische status

1. Welke diploma's hebt u reeds behaald?

- Geen diploma

- Lager onderwijs

- Algemeen secundair onderwijs (ASO)

- Technisch secundair onderwijs (TSO)

- Kunst secundair onderwijs (KSO)

- Beroeps secundair onderwijs (BSO)

- Professionele bachelor 
- Academische bachelor

- Master, licentiaat, postgraduaat of hoger

2. Wat is uw arbeidersstatuut?

- Werkloos

- Vrijwilliger

- Student

- Arbeider

- Bediende

- Zelfstandige

- Gepensioneerd

- Informeel (zonder contract)

- Andere:

3. Heeft u ooit niet kunnen voorzien in een van onderstaande zaken voor uw gezin? Duid aan welke. (Meerdere antwoorden mogelijk)

- Voedsel

- Kleding

- Huisvesting

- Gezondheidszorg

- Transport

- Geen van bovenstaande

Indien u 'geen van bovenstaande' antwoordde, sla vraag 6 en 7 over.

4. Indien u ooit niet heeft kunnen voorzien in één van bovenstaande zaken, hoe regelmatig was dit?

- Dagelijks

- Enkele keren per week

- Enkele keren per maand

- Enkele keren per jaar

- Eén keer per jaar

- Minder dan één keer per jaar

5. Ervaart u momenteel nog steeds deze moeilijkheden?

- Ja

- Nee

6. Hoe gemakkelijk kunt u/kan uw huishouden rondkomen met het totale beschikbare inkomen?

- Zeer gemakkelijk

- Gemakkelijk

- Eerder gemakkelijk

- Eerder moeilijk

- Moeilijk

- Zeer moeilijk

\section{Noodzaak}

In deze groep vragen willen we te weten komen hoe belangrijk deze organisatie is voor $\mathrm{u}$.

1. Hoe vaak komt u langs bij deze organisatie?

- Meerdere keren per dag

- Dagelijks

- Wekelijks 
- Maandelijks

- Jaarlijks

- Bijna nooit

2. Moet u minder spaarzaam met geld omgaan door deze organisatie? $\mathrm{Ja} / \mathrm{Nee}$

3. Hoe gemakkelijk is het om de diensten en producten van deze organisatie te gebruiken?

- Heel gemakkelijk

- Gemakkelijk

- Matig gemakkelijk

- Niet gemakkelijk

- Helemaal niet gemakkelijk

4. Hoe bereikbaar is deze organisatie voor u?

- Heel bereikbaar

- Bereikbaar

- Matig bereikbaar

- Niet bereikbaar

- Helemaal niet bereikbaar

5. Hoe noodzakelijk is deze organisatie voor u?

- Heel noodzakelijk

- Noodzakelijk

- Matig noodzakelijk

- Niet noodzakelijk

- Helemaal niet noodzakelijk

6. Wat zijn de grootste ongemakken die u ondervindt bij het gebruiken van de diensten of producten van deze organisatie?

7. Wat zijn de grootste comforten die $u$ ondervindt bij het gebruiken van de producten of diensten van deze organisatie?

8. Indien je meer geld bezat, zou je de diensten of producten van deze organisatie nog steeds gebruiken?

- Zeker wel

- Waarschijnlijk wel

- Niet meer of minder

- Waarschijnlijk niet

- Zeker niet

9. Zou u deze organisatie missen indien ze niet meer bestaat?

- Ja, heel hard

- Ja, toch wel een beetje

- Niet ja of nee

- Nee, niet echt

- Nee, helemaal niet

\section{Informatie en bewustzijn}

In deze vraaggroep willen we meer te weten komen over uw bewustzijn over de gevolgen van uw consumentengedrag. 
1. Bent u begaan met uw ecologische voetafdruk*?

${ }^{*} D e$ ecologische voetafdruk is een getal dat weergeeft hoeveel biologisch productieve grond- en wateroppervlakte nodig is om je consumptieniveau te kunnen handhaven, en om de afvalproductie te kunnen verwerken (Bewustverbruiken, 2018).

- Ja, heel hard

- Ja, toch wel een beetje

- Niet ja of nee

- Nee, niet echt

- Nee, helemaal niet

2. Hoeveel moeite kost het u om duurzamer, milieuvriendelijker of klimaat neutraler te leven?

- Heel veel

- Veel

- Matig

- Weinig

- Heel weinig

3. Moedigen organisaties en media je aan om duurzamer te leven?

- Ja, heel veel

- Ja, toch wel

- Niet ja of nee

- Nee, niet echt

- Nee, helemaal niet

- Geen antwoord

4. Moedigen personen in je omgeving je aan om duurzamer te leven?

- Ja, heel veel

- Ja, toch wel

- Niet ja of nee

- Nee, niet echt

- Nee, helemaal niet

- Geen antwoord

\section{ENGLISH VERSION}

Circular economy in Leuven

Dear reader,

We are four students from KU Leuven who are participating in a research project. Our research is about the circular economy and "prosumers" in Leuven. A prosument is a person who consumes and produces a product. "Prosumption" refers to the practice whereby one person creates certain products and services, and ultimately uses this product himself. In our project we are investigating how consumers can be turned into prosumers, with the aim of creating a more sustainable and circular economy in Leuven.

In our research we decided to focus on prosumer behavior among economically disadvantaged people in Leuven. According to various sources, consumer behavior is already present in the lifestyle of poorer people. They more often repair their own things, borrow expensive items and tools, and buy second-hand ones in order to avoid expensive costs.

Through this research we want to find out what the biggest driving forces are that ensure that someone exhibits prosumer behavior. Does this differ depending on one's place in society? Does prosumer behavior change when someone's socioeconomic status changes? 
Participants in this study are randomly selected. We use different questionnaires depending on the target audience. For example, there is a questionnaire specifically for second-hand store customers and one for second-hand store employees. We hope to gather information from these questionnaires so that we can successfully motivate consumers to become prosumers in the future.

The questionnaire is completely anonymous. There are no right or wrong answers; you can simply answer from your own experience. If you do not understand a question, you can always ask for more explanation.

Completing the questionnaire takes 5 minutes. Are you willing to complete the questionnaire? If you change your mind during or after completing the questionnaire, you can always stop and say that we may not use your answers in our research.

Thanks in advance and best regards,

Julie, Faysal, Nick and Mante

There are 18 questions in this survey divided into 3 groups.

\section{Status}

In this group of questions we would like to collect information about your socioeconomic status

1. What diplomas have you already obtained?

- No diploma

- Primary education

- General secondary education (ASO)

- Technical secondary education (TSO)

- Art secondary education (KSO)

- Vocational secondary education (BSO)

- Professional bachelor

- Academic bachelor

- Master's degree, postgraduate degree, or higher

2. What is your worker status?

- Unemployed

- Volunteer

- Student

- Worker

- Clerk

- Self-employed

- Retired

- Informal (without contract)

- Other:

3. Have you ever been able to provide your family with one of the things below? Indicate which. (Multiple answers possible)

- Food

- Clothing

- Housing

- Healthcare

- Transport

- None of the above

If you answered "none of the above", skip questions 6 and 7. 
4. If you have never been able to provide for one of the above, how regular was this?

- Daily

- Several times a week

- Several times a month

- Several times a year

- Once a year

- Less than once a year

5. Are you still experiencing these difficulties?

- yes

- no

6. How easily can you/can your household survive on your total disposable income?

- Very easily

- Easily

- Rather easily

- Previously difficult

- Difficult

- Very difficult

\section{Need}

In this group of questions we want to find out how important this organization is for you.

1. How often do you visit this organization?

- Several times a day

- Daily

- Weekly

- Monthly

- Annually

- Almost never

2. Do you spend less money by using the services or products of this organization? Yes/No

3. How easy is it to use the services and products of this organization?

- Very easy

- Easy

- Moderately easy

- Not easy

- Not easy at all

4. How accessible is this organization to you?

- Very accessible

- Accessible

- Moderately accessible

- Not accessible

- Not accessible at all

5. How necessary is this organization for you?

- Very necessary

- Necessary

- Moderately necessary 
- Not necessary

- Not necessary at all

6. What are the biggest inconveniences you experience when using the services or products of this organization?

7. What are the greatest benefits that you experience when using the products or services of this organization?

8. If you had more money, would you still use the services or products of this organization?

- Certainly

- Probably

- No more or less

- Probably not

- Certainly not

9. Would you miss this organization if it no longer existed?

- Yes, very much

- Yes, quite a bit

- Neither yes or no

- No, not really

- No, not at all

- No information $+$ 
Supplement 3: Video of the Presentation at the Symposium "KU Leuven Facing the Future", May 8, 2019, Leuven, Belgium.

The results of this work were presented at the symposium "KU Leuven facing the future", May 8, 2019, Leuven, Belgium. A video of this presentation can be found here. 